\title{
Oceanic inside corner detachments of the Limassol Forest area, Troodos ophiolite, Cyprus
}

\author{
J. R. CANN ${ }^{1}$, H. M. PRICHARD ${ }^{2}$, J. G. MALPAS ${ }^{3}$ \& C. XENOPHONTOS \\ ${ }^{1}$ Department of Earth Sciences, University of Leeds, Leeds, LS2 9JT. UK3 (e-mail: j.cann@earth.leeds.ac.uk) \\ ${ }^{2}$ Department of Earth Sciences, University of Cardiff, Cardiff, Wales CF10 3 YE \\ ${ }^{3}$ Department of Earth Sciences, Hong Kong University
}

\begin{abstract}
Flat-lying extensional detachment faults have been imaged in the inside corner regions of ridge transform intersections on the Mid-Atlantic Ridge. Exposed detachment surfaces are $10 \mathrm{~km}$ or more across, and are corrugated in the direction of spreading, as are continental detachments. Beneath the detachments lie core complexcs of peridotite and gabbro; these are overlain by blocks of crustal material. We argue here that similar detachments are an essential component of the Limassol Forest area of the Troodos ophiolite in Cyprus, which lies south of the Arakapas Fault zone, previously recognized as a palaeo-transform fault, and here interpreted as a transform lault that evolved into a fracture zone. In the Limassol Forest, core complexes of mantle peridotite can be shown to have been exposed at the sea floor, or to have been covered by overlapping crustal blocks, separated from the peridotite core and from each other by low-angle extensional faults. The extension can be shown to have occurred shortly after crustal construction. and the already extended terrain was then intruded by swarms of dykes and plutons. We interpret these relations as arising when crust is constructed in an inside corner area, extended by detachment faulting. deformed further during slip along the transform. and then intruded by new magma as it passes the second spreading centre. The structurally deeper parts of the crustal blocks that overlie the detachment lie broadly towards the west, indicating that the spreading axis lay in that direction. The ophiolite north of the transform is much less extended. and we interpret this as a section of outside corner crust. In this interpretation, the Troodos ophiolite formed to the east (in its current orientation) of a ridge-transform-ridge intersection, in which the transform had a dextral offset and sinistral slip. The part of the ophiolite that forms the Limassol Forest was produced at the western inside corner, and spread eastwards until it passed the second spreading axis, at which point the ophiolite north of the Arakapas Fault was created and welded to the Limassol Forest when the transform became a fracture zone.
\end{abstract}

Keywords: Troodos ophiolite, detachment faults, transform faults, metamorphic core complexes.

Oceanic transform faults are sites of abundant outcrops of the oceanic lower crust and upper mantle (Bonatti \& Hamlyn 1981). Most of these plutonic rocks come from the inside corners of transforms, the strips of crust generated in the angle between the spreading centre and the active transform fault (Fig. 1) (Bonatti \& Michael 1989; Dick 1989; Cannat et al. 1995). The plutonics are considered to have become exposed by extension on detachment faults dipping from the inside corner towards the outside corner (Dick et al. 1981; Karson \& Dick 1983; Mével et al. 1991: Tucholke \& Lin 1994), resulting in the removal of upper crust to expose plutonic rocks. Such faults have been observed from submersibles. and penetrated by drilling of an inside corner high close to the spreading axis in the MARK area of the Mid-Atlantic Ridge at $23^{\circ} \mathrm{N}$ (Karson \& Lawrence 1997a). More recently, bathymetric and side-scan sonar images of the inside corners of the Atlantis Transform at $30^{\circ} \mathrm{N}$ show flat-lying corrugated detachment fault surfaces which cap active and fossil inside corner highs (Cann et al. 1997: Blackman et al. 1998). Plutonic rocks have been recovered from the massifs that underlie the detachment surfaces in both the MARK and Atlantis areas, and, in both areas, blocks of upper oceanic crust appear to overlie the detachments (Mével et al. 1991; Karson \& Lawrence 1997a; Blackman et al. 1998).

In the Troodos Ophiolite in Cyprus, the Arakapas Fault is considered to be a fossil oceanic transform fault exposed on land (Moores \& Vine 1971; Simonian \& Gass 1978). North of the fault. the structural units of the ophiolite overlie one another in an orderly sequence, but to the south, in the Limassol Forest, units of the ophiolitic sequence are juxtaposed in a complex way, so that, for example, mantle material lies next to sheeted dykes or even lavas. This area has been interpreted by MacLeod \& Murton (1993) and Gass et al. (1994) partly as a broad transform-tectonized zone or leaky transform fault domain associated with the Arakapas Fault, and partly as part of an 'Anti-Troodos Plate' deformed by late extension. Malpas of al. (1993) showed that inliers of the Troodos Complex immediately west of the Limassol Forest are dominated by extensional structures. with little evidence of strike-slip movements. They considered that this extension extended east into the main Limassol Forest. and took place in a proto fore-arc environment.

In this paper we propose an alternative model, in which the Limassol Forest is interpreted as a whole, and is considered to have formed at an ancient inside corner of a ridgetransform intersection. We consider that the complex lithological and structural relationships of the Limassol Forest are the result of extreme extension, in which flat-lying or arched detachment faults can be identified, similar to those imaged in the oceans. These faults form two culminations, one to the west which became exposed at the sea floor, and the other to the east that remained covered with extended crustal units. This interpretation leads in turn to a reinterpretation of the ancient spreading environment in which the Troodos ophiolite 


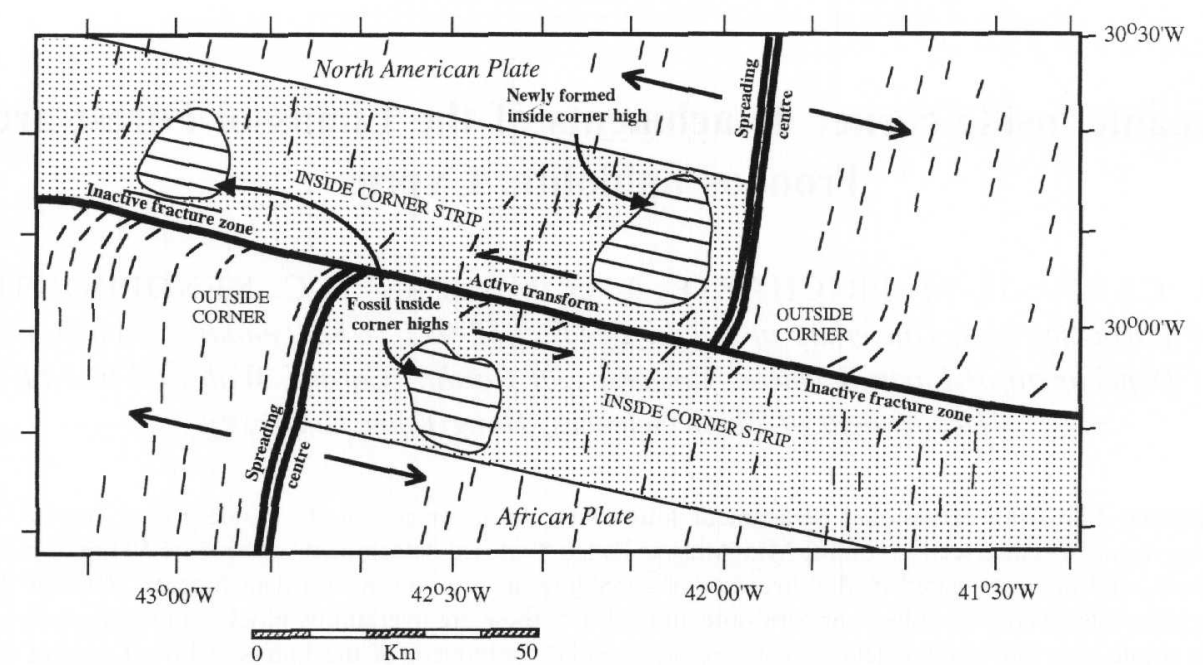

Fig. I. Summary geological overview of the Atlantis Transform Fault at $30^{\circ} \mathrm{N}$ in the Mid-Atlantic Ridge. See Cann et al. (1997) and Blackman et al. (1998) for detailed explanation. The active transform fault lies between the two spreading axes. Note that the sense of shear and the sense of displacement are opposite in a transform fault. Beyond the spreading centres on each side of the active zone the fault is inactive. and is termed a fracture zone. Crust formed at one of the inside corners moves first along the transform fault, shearing against inside corner crust formed at the other spreading centre until it reaches that spreading centre. There magmatic activity constructs new outside corner crust which is welded onto the inside corner crust as it passes from the transform fault to the fracture zone. While the transform fault separates crust formed on two different plates. the outside corner crust that welds to the inside corner crust as it passes into the fracture zone belongs to the same plate. At intervals along the inside corner strip are the elevated massifs that are active or fossil inside conner highs. On these massifs are exposed the corrugated surfaces described in the text. with corrugations oriented parallel to the spreading direction (striped areas on the figure). These surfaces appear to be outcropping detachment faults. Note the scale of the exposed detachment surfaces and of the zone of inside corner crust. Samples of fresh, weathered and metamorphosed basalts, of variously deformed and altered gabbros, and of harzburgites and dunites were recovered from the inside corner strips. Dashed lines generally parallel to the spreading axes show the location of topographic ridges. most of them carrying a clear bathymetric signature of volcanism, representing periods of increased magmatic activity at the spreading centres, and fed by fissures running parallel to the ridges that become dykes in the mature crust (Ballard \& van Andel 1977). Note that many of these ridges curve in the direction of offset of the transform fault over the $5-0 \mathrm{~km}$ closest to the transform fault or fracture zone. This curvature is most marked in the outside comer strips.

formed, which is significantly different from those previously published.

\section{Oceanic detachments}

Before discussing the Limassol Forest, we first describe oceanic detachments and the environment in which they form. At outside corners and centres of spreading segments. basaltic lavas are by far the most abundant rock type exposed at the surface. Eruptional features such as small seamounts and fissure ridges are common on sonar images of the young rocks of the axial regions, and are preserved off axis until they are covered by sediment (Smith \& Cann 1993; Smith et al. 1995). Trends of fissure ridges probably represent the trends of underlying feeder dykes, which can thus be mapped on the ocean floor (Smith \& Cann 1999). The lavas are cut by steep normal faults which have a maximum throw of a few hundred metres at slow spreading centres, and smaller throws at faster spreading rates (Macdonald 1982). Most of the extensional strain in these regions is accommodated by intrusion of dykes and plutonics and eruption of lavas; only $10 \%$ or so is taken up by faulting (Cowie et al. 1993; de Chablier \& Avouac 1994; McAllister 1995; Escartin et al. 1999). Seafloor morphology indicates that magma is supplied more abundantly at the segment centres than at the segment ends, and that it also fluctuates through time at both segment centres and ends (Ballard \& van Andel 1977: Karson et al. 1987).

Bathymetric maps and sonar images show, by contrast, that the strips of crust generated at inside corners are characterized by blocky topographic highs, the inside corner highs, that form intermittently close to the inside corners and then are rafted away (Searle \& Laughton 1977; Karson \& Dick 1983; Collette 1986; Severinghaus \& Macdonald 1988). These are separated by areas of irregular topography. Plutonic rocks are commonly recovered from these inside corner strips, and, because rates of erosion on the deep ocean floor are slow, must have been exposed there by faulting. A suitable mechanism is extensional detachment faulting, in which the faults dip from the inside corner towards the outside corner and separate upper crust in the hanging wall from lower crust or upper mantle in the footwall (Dick et al. 1981; Karson \& Dick 1983; Mével et al. 1991; Tucholke \& Lin 1994). Until recently the most compelling evidence for such a detachment came from the MARK area at the eastern ridge-transform intersection of the Kane Fracture Zone in the North Atlantic (Karson \& Dick 1983; Mével et al. 1991: Karson \& Lawrence 1997a, b), showing that upper and lower crustal units are separated by faults with both brittle and ductile deformation fabrics. Models for such detachment faults have evolved over the years. The most recent is that of Tucholke \& Lin (1994), based on that of Buck (1988) Buck (1988), in which the detachment is envisaged as steepening towards the spreading axis and terminating in the brittleductile transition below the axis itself, rather than, as in previous models, extending across the axis to underlie the outside corner crust.

In 1996 a new survey was made of the inside corner areas of the Atlantis Fracture Zone at $30^{\circ} \mathrm{N}$ on the Mid-Atlantic Ridge, $800 \mathrm{~km}$ north of the Kane Fracture Zone (Cann et al. 1997: 


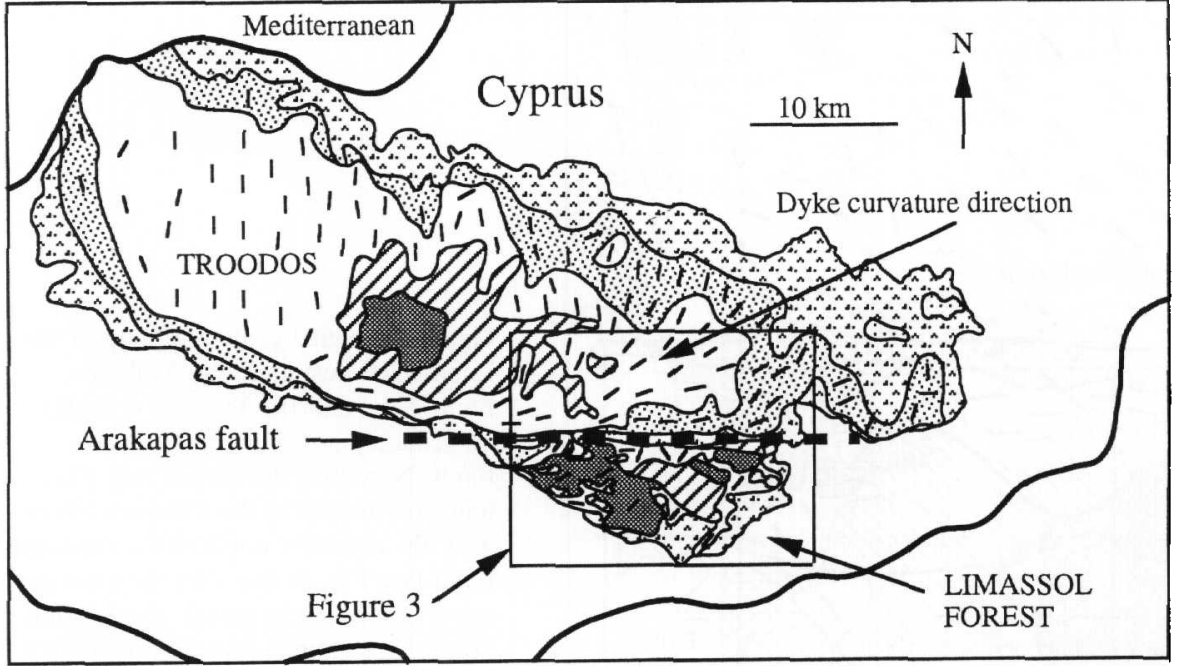

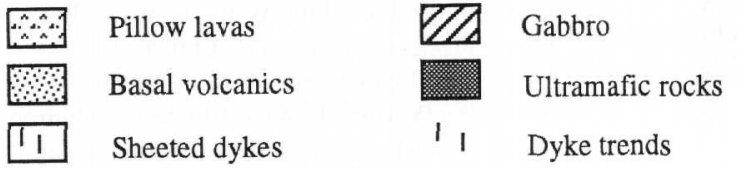

Fig. 2. Simplified geological map of the whole of the Troodos ophiolite, based on maps of the Cyprus Geological Survey. and showing the regular arrangement of lithologies north of the Arakapas Fault, in the classic stratigraphic order of an intact ophiolite, compared with the much more disorganized arrangement of the same lithological units in the Limassol Forest (see also Fig. 3). Note the curvature of the dyke trend as the east west Arakapas Fault is approached from the north. The box outlines the area covered in Figure 3.
Blackman et al. 1998) (see Fig. 1). The strips of crust generated at the inside corners contain three inside corner high massifs, $10-20 \mathrm{~km}$ across, rising several hundred metres above the surrounding sea floor, and separated by deeper areas of more irregular topography. On the top of the massifs, the survey imaged flat-lying corrugated and striated surfaces up to $10 \mathrm{~km}$ across that are considered to represent detachment faults exposed at the sea floor. The corrugations run parallel to the spreading direction; similar transport-parallel corrugations have been observed on low-angle detachment faults in the Basin and Range area of the western USA (John 1987; Davis \& Lister 1988). Dredges from the corrugated surfaces and from exposures of rocks underlying them recovered serpentinized peridotites and basalt. One of the massifs lies very close to the eastern spreading centre, so that the detachment fault there may still be active. Detachment faults capping the other massifs, which lie on crust $1-3$ million years old, must now be inactive. On the massif at the eastern ridge-transform intersection, the corrugated detachment surface can be seen overlain, close to the median valley, by a fault block with a hummocky, volcanic morphology on its upper surface, separated by a steep normal fault from volcanic median valley floor (Blackman et al. 1998, fig. 3). Since the Atlantis detachments were discovered, similar structures have been identified elsewhere in the Atlantic (Tucholke et al. 1998; Mitchell et al. 1998; Karson 1999).

The regions of the inside corner strips between the massifs have a very different bathymetric character from the massifs Parts of them show the bathymetric or sidescan sonar signature of volcanic topography which characterizes the outside corner crust and the crust formed on both sides of the middle sections of spreading segments (Smith et al. 1995). In other areas, however, the strips are made up of irregular mounded topography which is seen on side scan sonar records to be made of outcrops of fissured and faulted basement rock. Dredges from these regions of irregular topography recovered a wide range of rock types, including basalts, gabbros and more or less serpentinized peridotites
(Blackman et al. 1998). The presence of plutonic rocks here suggests that these regions too have been highly extended.

Within the transform, the active zone of faulting is narrow, less than $1 \mathrm{~km}$ wide, and is clearly imaged both by bathymetry and side-scan sonar (Parson \& Searle 1986; Zervas et al. 1995: Blackman et al. 1998). In the active part of the transform, between the two spreading centres north and south of the transform fault, inside corner crust generated at one spreading centre slips past inside corner crust generated at the other (see Fig. 1). In the inactive parts of the transform, termed the fracture zone, which are outside and beyond the active section, inside corner crust generated at one spreading centre lies passively next to younger outside corner crust generated at the other. During spreading, inside corner crust is formed by magmatic and tectonic activity at one spreading centre, then slips along the active transform undergoing deformation, next passes the second active spreading centre where magmatic activity may be renewed, and finally enters the inactive fracture zone where it is welded against new outside corner crust. Active volcanism that covers the transform fault as it becomes inactive can be seen at the western ridge-transform intersection of the Atlantis Transform Fault in the Atlantic (Smith et al. 1999); volcanism can be seen to extend well beyond the transform fault into the opposite inside corner terrain in several transforms in the Pacific (e.g. Gallo et al. 1986). These relationships are important in what follows, and are shown on Figure 1, which is a simplified geological map of the Atlantis Transform emphasizing its different structural elements.

\section{The Limassol Forest}

\section{Relationship to the rest of the Troodos ophiolite}

The Troodos ophiolite, Cyprus (Fig. 2), is divided into two parts, the main ophiolite north of the Arakapas Fault, and the Limassol Forest south of it (Gass 1968; Simonian \& Gass 1978; Gass et al. 1994). The Arakapas Fault Zone is about a 


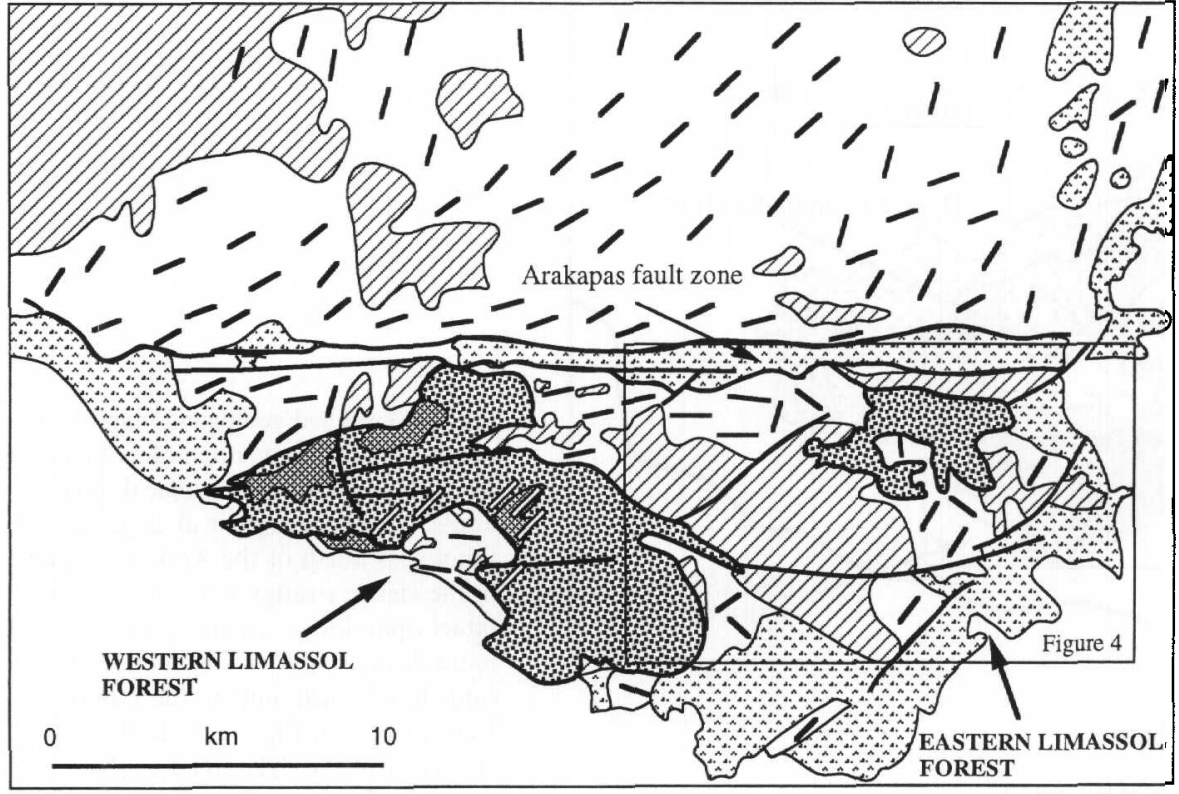

\begin{tabular}{|c|c|c|}
\hline$\therefore$ & Extrusives & Post ophiolite sediments \\
\hline L & Sheeted dykes with dyke trends & Late dykes \\
\hline E & Gabbro & Late gabbros and wehrlites \\
\hline $\mathrm{Br}$ & Ultramafic harzburgite and dunite & Fault \\
\hline
\end{tabular}

Fig. 3. Simplified geological map of the Limassol Forest area, the Arakapas Fault Zone and the Troodos ophiolite immediately north of the Arakapas Fault. Note that the same lithological units are present in the Limassol Forest as in the ophiolite north of the Arakapas Fault (see Fig. 2), but that the units are not arranged in the classic stratigraphic order; for example. lavas are in contact with all other lithological units. The map shows the relationships between the Western and Eastern Limassol Forest. and the distribution of lithologies within the Western Limassol Forest. including the dykes and plutons formed during the second phase of igneous activity. The box outlines the area of Figure 4 . The figure is based on the detailed maps of Gass et al. (1991) and of the Cyprus Geological Survey. kilometre wide, running east west at right angles to the overall trend of the sheeted dykes in the ophiolite. It formed a topographic trough. which was progressively filled with coarse clastics shed from the surrounding sea floor, with finer-grained hydrothermally-derived sediments, and with submarine lava flows. The basement of the trough shows intense cataclastic deformation. the intensity of which rapidly reduces upwards within the sedimentary and volcanic fill of the trough, suggesting that much of this fill was emplaced just as the fault zone became inactive. Fault strands show strike-slip slickensides. All of these features are considered consistent with the Arakapas Fault Zone having been a transform fault offsetting the spreading axis during the mid-Cretaceous construction of the ophiolite (Simonian \& Gass 1978; MacLeod \& Murton 1993; Gass et al. 1994). The width of the fault zone. and its existence as a topographic trough, are similar to the features of the Atlantis Transform described above, and to other transforms for which detailed surveys are available (OTTER team 1985; Searle 1986; Gallo et al. 1986: Macdonald et al. 1986: Madsen et al. 1986).

North of the Arakapas Fault, the ophiolite, arched into a dome since the Miocene, and subsequently eroded, shows the classic sequence of units of seafloor sediments, submarine lavas, sheeted dykes, gabbros and ultramafic rocks including mantle harzburgites and dunites, each overlying the next (Fig. 2). Generation of this crust at a spreading centre is demonstrated by the unit of sheeted dykes, about $1 \mathrm{~km}$ thick, in which the dykes strike generally north -south, extending for more than $70 \mathrm{~km}$ across strike. The lava unit and the sheeted dykes are cut by numerous steep faults, most of which strike parallel to the dykes, and most of which do not cut the overlying sediments (Gass 1960: Dietrich \& Spencer 1993; Agar \& Klitgord 1995). Many of these faults contain veins of epidote. quartz and pyrite. showing that they acted as conduits of hot watcr, probably associated with the sulphide deposits that form part of the lava sequence, and were thus active during crustal construction. Within the sheeted dyke unit, though the faults are conspicuous, slip on them makes up a relatively small proportion of the extensional strain. which can be accounted for mostly by dyke intrusion (Agar \& Klitgord 1995). More extension takes place at depth in the sheeted dyke complex through movement on low-angle detachment faults (Varga \& Moores 1985; Agar \& Klitgord 1995), leading to rotation of blocks of sheeted dykes. This extension, though spectacular in the field, is never enough to result in the omission of a major lithological unit. Nowhere in the section to the north of the Arakapas Fault is the structure of the ophiolite disrupted by the omission of one of the major structural units. All of these features in the ophiolite north of the Arakapas Fault show strong parallels with oceanic crust formed at the centres of spreading segments or in outside corner regions.

In the Limassol Forest south of the Arakapas Fault, similar lithological units are present. including major units of sheeted dykes, demonstrating an origin at a spreading axis. but these units show much more complex relationships (Fig. 3). Outcrops of mantle lithologies several kilometres across are in tectonic contact with a range of crustal lithologies including cumulate ultramafics, gabbros, sheeted dykes and lavas: in places deep crustal lithologics lie next to units of submarine lava. These complex relationships are observed for about $10 \mathrm{~km}$ south of the Arakapas Fault Zone (Bear \& Morel 1960; Pantazis 1967: MacLeod \& Murton 1993; Gass et al. 1994). The following description of the Limassol Forest draws on the excellent pioneer mapping of the Western Limassol Forest by B. J. Murton and of the Eastern Limassol Forest by C. J. MacLeod. The map was published as Gass et al. (1991), with the resulting memoir as Gass et al. (1994): (see also Murton \& 
Gass 1986: Murton 1989, 1990; MacLeod 1990; MacLeod \& Murton 1993). Because in these works the two parts of the Limassol Forest are considered to have had different origins, we describe them here separately, though our model interprets them as different aspects of the same process.

\section{The Western Limassol Forest}

The Western Limassol Forest (Fig. 3) is dominated by a major core unit of ultramafic rock, about $10 \mathrm{~km}$ across, predominantly of serpentinized harzburgite, with subsidiary serpentinized dunite, and rare gabbro pods altered to rodingite. The serpentinized harzburgite has a gneissic fabric shown by the orientation of the bastite pseudomorphs after orthopyroxene, typical of sub-ophiolitic upper mantle. This unit is cut by vertical serpentinite shear zones, up to hundreds of metres wide and a few kilometres long: other serpentinite shear zones in a variety of orientations separate the ultramafic core from the surrounding units. Scattered throughout the ultramafic core, though concentrated towards its centre, is a suite of late igneous intrusions, including picritic and basaltic dyke swarms trending dominantly NE-SW, and a number of small gabbro and wehrlite plutons. Both plutons and dykes truncate the gneissic fabric of the harzburgite and are themselves undeformed. Olivine in the plutons is only partly serpentinized. The dykes chill against the serpentinized peridotite, and also post-date most of the movement on the serpentinite shear zones, since undeformed dykes can be seen to cut the sheared serpentinite.

Around the edges of this ultramafic core are complex units of crustal material, including submarine lavas, sheeted dykes, and a range of gabbros and ultramafic cumulates These are apparently in fault contact with the ultramafic unit. In places, the fault contact is one of the steep serpentinite shear zones, but in other places, such as at the east end of the ultramafic core, the contact is gently dipping, with the crustal units overlying the ultramafic unit. Along the SW edge of the Western Limassol Forest the relationships are disturbed by a Miocene compressional event, but in this area, close to the village of Akrounda, a sedimentary breccia is seen interbedded with submarine lava flows that form part of one of the crustal units (Gass et al. 1994). This breccia contains clasts of serpentinite as well as of lava. showing that serpentinite was exposed to erosion at the sea floor during the time of lava eruption there.

\section{Eastern Limassol Forest}

We consider that this part of the Limassol Forest is exposed at a particularly critical structural level, since in this area a flat detachment fault separates mantle from crustal units. Figure 4 is a simplified summary map of the Eastern Limassol Forest. based on that of Gass et al. (1991). The boundary between the mantle lithologies and all of the crustal lithologies is an intricate line on the map, but for much of its length this intricacy is the result of the outcrop of low-angle contacts in an area of complex topography. In many places, and especially around grid square 2052 (Fig. 4), the intricate fault contact between the mantle rocks and the crustal rocks can clearly be seen in the field to follow the topographic contours, with crustal units above, and mantle units below. This boundary is the Akapnou Forest Décollement of Gass et al. (1994. p. 159), here termed the Akapnou Detachment. Figure 5 is a structure contour map of that surface. based on the geological map of Gass et al. (1991). It forms a relatively smooth whaleback, plunging towards the east at about $100 \mathrm{~m}$ every $4 \mathrm{~km}$ (about $2^{\circ}$ ) and dipping north and south at angles up to $10^{\circ}$. The omission of structural units across this boundary. which over large parts of the area brings sheeted dykes in direct contact with mantle lithologies, suggests that it represents a major extensional fault. Figure 6a shows a schematic, and somewhat simplified, east-west cross section along northing 52 in Figure 4 , using the evidence from the map relationships of Gass et $a l$. (1991), supplemented by our own field observations.

In the field, the boundary between crustal units and mantle units is marked by a zone of sheared serpentinite, which overlies more massive largely serpentinized, harzburgite and dunite (Gass et al. 1994). Within this shear zone, individual flat-lying shears are common, running approximately parallel to the overall orientation of the boundary; in some places, where the shearing is more penetrative than in others. a top to the west sense of motion can be deduced from S-C fabrics, and there is also a late steep crenulation cleavage.

We interpret the crustal rocks above the shear zone to be divided into three major structural units, numbered 1, 2 and 3 on Figure 4, and distinguished there and in the cross section of Figure 6a by different intensities of shading. Each structural unit has been divided into three parts, (a) upper crust, composed of lavas and sheeted dykes, (b) middle crust, composed of high-level gabbros, which may be isotropic or wispily layered and often uralitic, and (c) lower crust composed of well-layered gabbros and wehrlites (see Gass et al. 1991). The most conspicuous of the structural units is Unit 2. which occupies most of the centre of Figure 4, and a major part of the cross section in Figure 6a. Though this unit has been dissected by a number of normal faults, it shows a coherent internal stratigraphy which includes a wide range of crustal lithologies. The deeper crustal levels within this unit lie towards the SW, while the shallower levels lie towards the NE. Layered gabbros at the deeper levels have been rotated so that their layering is nearly vertical (Gass et al. 1991). In the centre of Figure 4 and towards the right hand side of Figure 6a, this unit can be seen to overlie another crustal unit, Unit 1, and to be separated from it by a flat-lying shear zone. Shallower crustal lithologies in Unit 2 overlie deeper crustal lithologies in Unit 1, indicating an extensional geometry for the shear zone that separates them. Unit 1 can be traced across a structural window to close to the eastern edge of the map. The deeper lithologies in Unit 1 lie west of its shallower lithologies; close to the Kalavasos Dam, near the eastern edge of its outcrop, pillow lavas forming the upper part of Unit 1 are vertical, strike NW-SE and young to the NE.

Towards the western edge of Figure 4 parts of another unit, Unit 3, are exposed. Again, the deeper lithologies in this unit lie towards the west. The contact between Units 2 and 3 appears to be a steep normal fault at the present levels of erosion, but by analogy with the boundary between Units 1 and 2, at other structural levels this may be a flat-lying shear zone. The sense of extension during this deformation would have been top to the SW, to judge from the strike of the rotated lavas, and the outcrop pattern of the crustal units. Scattered basaltic to doleritic dykes intrude into and chill against the ultramafic units beneath the Akapnou detachment and also intrude the deeper crustal units above the detachment. We correlate these late intrusives with the similar late intrusives of the Western Limassol Forest (see above). 


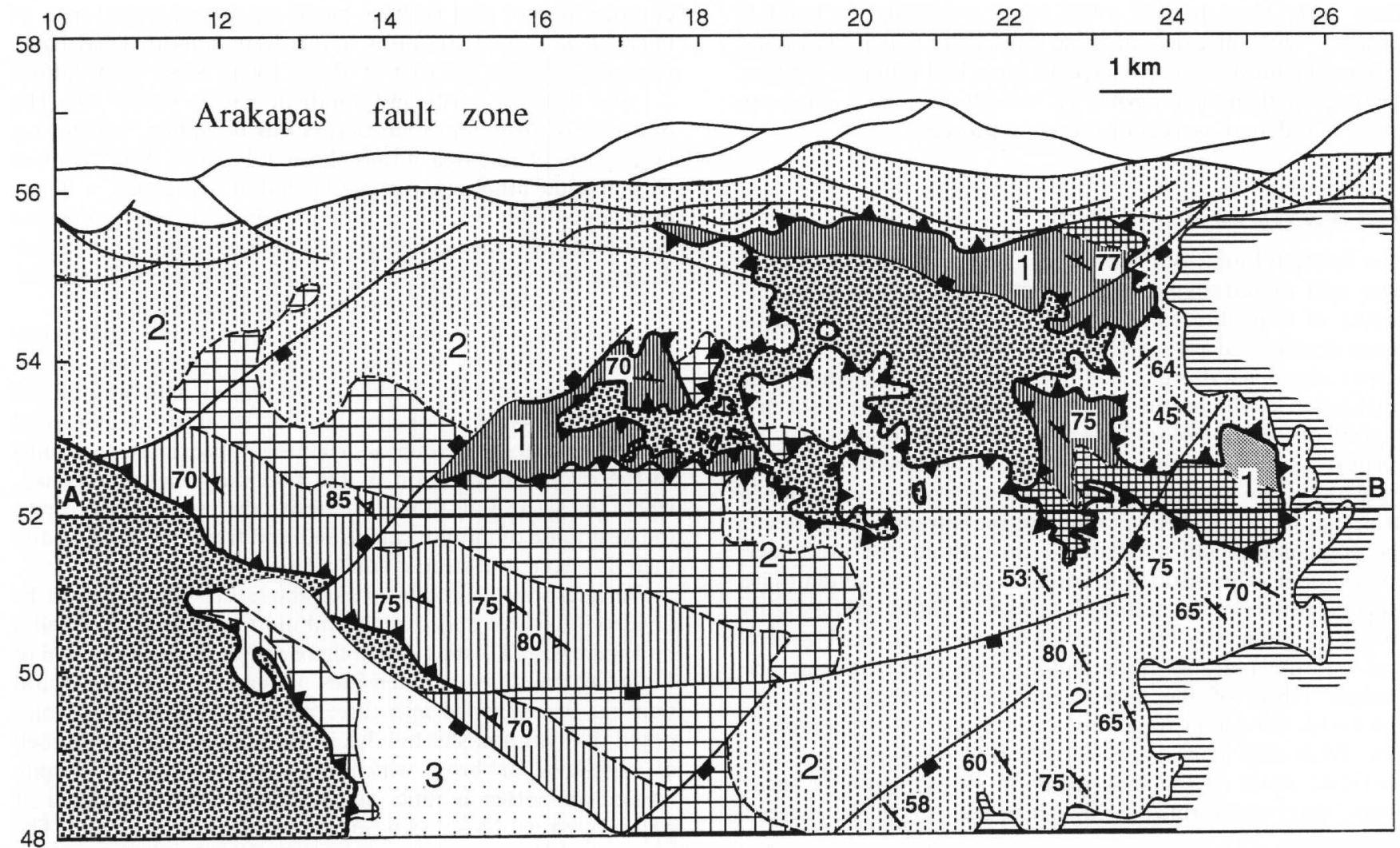

Fig. 4. Simplified geological and structural map of the eastern Limassol Forest, based on the geological mapping of C. J. MacLeod and E. Gcorgiou, from Gass ef al. (1991, 1994). The Arakapas Fault Zone runs east -west across the top of the map as a $1 \mathrm{~km}$ wide belt of fault strands. Within the northern part of the fault belt and north of it are sheeted dykes belonging to the main section of the Troodos ophiolite. South of the fault belt is the Limassol Forest area. This is unconformably overlain by post-ophiolitic sediments. Within the Limassol Forest, mantle lithologies include units mapped as tectonized harzburgite with minor dunitic and lherzolitic masses, and dunite. Crustal lithologies are separated into lower crust (ornamented with vertical stripes, and including units mapped as layered gabbros, layered and massive plagioclase wehrlitc, and cumulate peridotite), middle crust (ornamented with a square pattern. including units mapped as isotropic and leucocratic gabbros, with wispy layering and uralitic alteration) and upper crust (ornamented with dots. and including units mapped as sheeted dykes and extrusives). Three separate extensional sheets are numbered 1.2 and 3 . and are identified from structural relationships determined in the field and from the geological map of Gass et al. (1991). The lower unit. Unit 1, is shaded darker than the middle unit, Unit 2, which is in turn shaded darker than the upper unit. Unit 3. High-angle faults, whether normal faults or strike slip faults, are distinguished from low angle faults, here considered to be extensional, and marked by teeth on the hanging wall. The distinction between the two was made from outcrop pattern. supplemented by field observations.

\section{Timing of the extension}

MacLeod (in Gass et al. 1994) considers, on the basis of relationships in the sedimentary fill of half-grabens displacing the top of the volcanic succession, that extension on the Akapnou Detachment and related faults was prolonged over many millions of years, and continued long after the ophiolite had been constructed on the ocean floor. We disagree. From our own observations, we conclude that the sedimentary evidence used by Macleod to make the case for prolonged extension can be interpreted as consistent with very early extension, followed by prolonged sedimentation, with possible minor reactivation of the early faults.

Persuasive evidence in favour of early extension comes from the second phase of igneous activity in both Western and Eastern Limassol Forest. Dykes from this second phase cut the sheared serpentinite of the extensional fault zones. and the dykes both above and below the detachment share a similar orientation, showing that the second phase of igneous activity post-dated the extension. If the episode of extension was prolonged, and the second phase of igneous activity took place

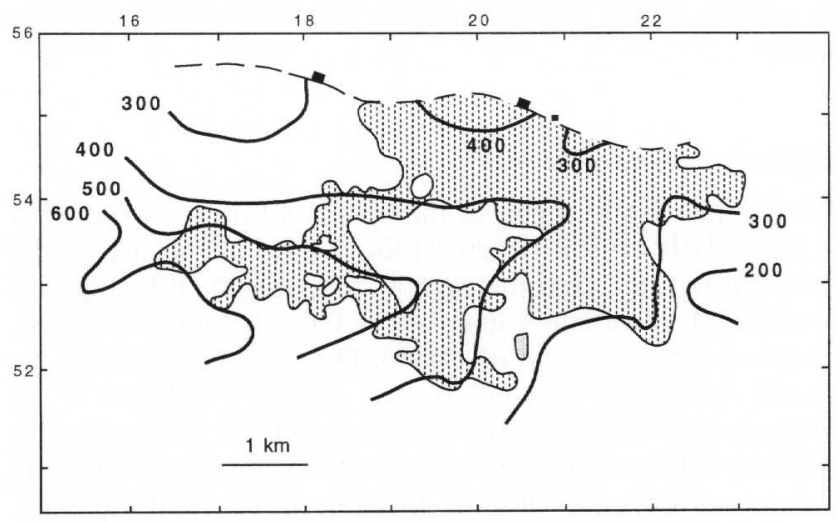

Fig. 5. Structure contours in metres on the boundary between the mantle lithologies and the crustal lithologies in the central part of Figure 4 ( $100 \mathrm{~m}$ contour interval). The structure contours were derived from the outcrop of the contact between the two groups of lithologies as mapped by C. J. MacLeod (Gass et al. 1991), and from topographic contours from 1:50 000 topographic maps. 


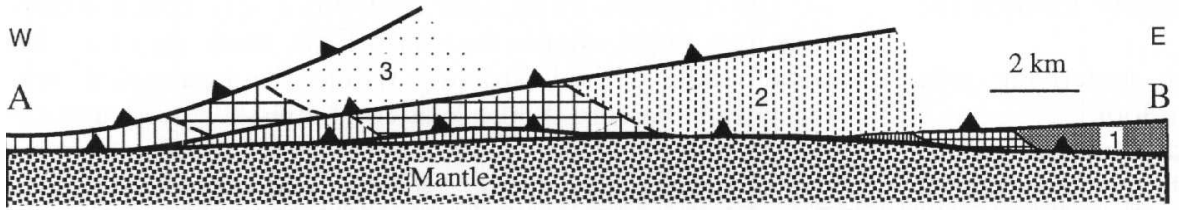

b

E

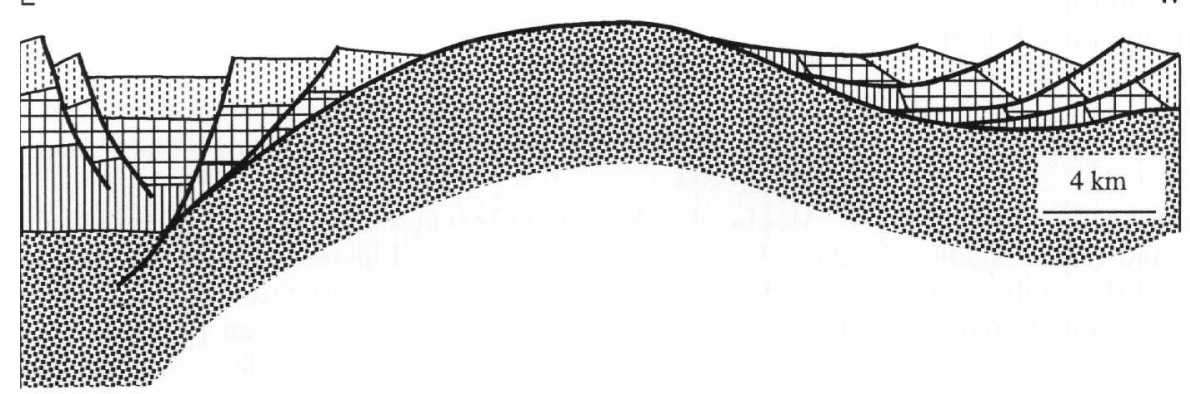

Fig. 6. (a) Schematic east-west cross-section through the eastern Limassol Forest, along the northing grid line 52 in Figure 4, before uplift and erosion. Units are identified in the same way as they are on Figure 4 , and the subdivisions into upper. middle and lower crust are the same. Steep normal laults have been omitted from the section. The present level of outcrop is close to the detachment between the mantle and crustal lithologies.

(b) Schematic east west cross-section through the eastern ridge transform intersection of the Atlantis Transform Fault, based on the model derived from the Cyprus field relations, and on constraints from bathymetry, deep-towed side scan sonar and dredges (see Cann et al. 1997 and Blackman $e t$ al. 1998). Crustal units are subdivided in the same way as in Figure 4. The cross section is viewed from the north to bring it into coincidence with the Cyprus cross section of (a). many millions of years after crustal construction, then lavas associated with this second phase would be expected to be separated from an earlier unit of volcanics by a unit of sediments. The almost undeformed lavas that form part of the fill of the Arakapas Fault trough can be related geochemically to the late dykes in the Limassol Forest. and are probably their extrusive equivalent (Gass et al. 1994). In the Arakapas Fault trough there no evidence of a prolonged hiatus between two phases of lava extrusion. In the ophiolite north of the Arakapas Fault where the simpler sequence would be expected to be especially sensitive to a hiatus, there is equally no evidence for a significant break in volcanism. Thus we consider that the second phase of igneous activity must have followed on very shortly after crustal construction.

\section{The Limassol Forest as an inside corner terrain}

\section{The inside corner model}

In the inside comer model, the Limassol Forest represents a $10 \mathrm{~km}$ wide strip of inside corner terrain generated at a spreading centre that lay west of the ophiolite in its present orientation, as shown by the sense of structural deepening of the extended crustal units above the detachment (Fig. 6). The transform fault is represented by the Arakapas fault zone, and would have had a dextral offset and sinistral slip. The ophiolite north of the Arakapas Fault would be a section of outside corner crust constructed as the inside corner terrain passed the spreading axis that lay to the north of the transform.

The Limassol Forest crust would have been constructed as normal ophiolitic crust at the spreading centre, with units of extrusives, sheeted dykes and crustal plutonics overlying ophiolitic upper mantle, very similar at that stage to the outside corner crust north of the Arakapas. Very shortly after crustal construction the lithosphere was extended radically, along a detachment fault separating mantle from crustal units. The crustal units themselves were separated by branches of the main detachment. In the Eastern Limassol Forest, the exten- sion ended when the detachment was still covered by rotated flakes of crustal blocks, whereas in the Western Limassol Forest the detachment fault became exposed at the sea floor. as shown by the presence of serpentinite clasts within sediment between lava flows. The exposed serpentinite dome was surrounded and partly overlain by crustal blocks. During the extension, or shortly after it, the mantle units became largely serpentinized.

The deformed inside corner terrain slid along the active transform until the terrain reached the second spreading axis. Magmatic activity was renewed at about the same time that strike slip movement ceased on the transform. Lavas were extruded into the transform trough, and remained almost undeformed, while swarms of dykes and groups of small gabbro and wehrlite plutons were emplaced into the deformed and serpentinized inside corner terrain. The NE-SW orientation of these late dykes was controlled by the rotated stress field close to the ridge-transform intersection. At this stage, or shortly afterwards, deformation ceased as the inside corner terrain became welded to the newly created outside corner crust to the north.

\section{Testing the inside corner model}

If we are to make the case that the Limassol Forest formed in an inside corner, similar to the inside corners of the Atlantis Transform at the Mid-Atlantic Ridge, a number of requirements ought to be satisfied.

(1) The Limassol Forest should be adjacent to a fossil transform fault, and. on the other side of the fault, to a strip of outside corner crust.

(2) The earliest history of the Limassol Forest should be of construction at a spreading centre, with crustal and mantle units typical of ophiolitic lithosphere.

(3) These units should have been greatly extended very shortly after crustal construction.

(4) Within this extended terrain, detachment faults should separate tectonic slices. leading to omission of structural units from the ophiolitic succession. 
(5) The crustal units in the hanging walls of these detachments should be rotated, and show a consistent sense of structural deepening. which would be broadly towards the location of the spreading axis.

(6) In places the detachment and the underlying core complex may have been exposed at the sea floor.

(7) Some time after the extensional event, renewed igneous activity may have occurred as the extended lithosphere passed the second spreading centre, and the transform became inactive. Products of this second phase of igneous activity should be almost undeformed, and should cross-cut the extensional structures and the strike-slip faults of the transform zone.

(8) he spatial scales of the structures in the Limassol Forest, and of the associated transform and region to the north of it, should be similar to those on the ocean floor.

How do the observations in the Limassol Forest match these requirements?

The Limassol Forest lies to the south of the Arakapas Fault Zone, long identified as a fossil transform, and it is a highly extended terrain. The ophiolite to the north of this fault zone is much less extended, and preserves intact the normal ophiolite stratigraphy. The nature of the crustal units present in the Limassol Forest is the same as in the ophiolite to the north, demonstrating construction at a spreading centre. We have argued above that the extension of the crust, and uplift and serpentinization of the mantle. must have happened very shortly after crustal construction.

The style of the extension involves, in the Eastern Limassol Forest, a flat detachment fault separating crustal units from mantle units, with low-angle faults arising from this to separate the crustal units from one another. The crustal units in the Eastern Limassol Forest all show the same sense of structural deepening, in this case towards the SW, consistent with a spreading axis lying to the west. These conclusions cannot be established so clearly in the Western Limassol Forest, but the relationships there are consistent with a more arched detachment fault eroded to a deeper structural level, and surrounded by crustal blocks very similar to those further east. Certainly there must have been major extension in the Western Limassol Forest to bring upper crustal units into contact with mantle units. Crustal Units 2 and 3 of the Eastern Limassol Forest overlap the eastern margin of the ultramafic core of the Western Limassol Forest. Occurrence of serpentinite clasts between lava flows in the southern part of the Western Limassol Forest suggests that its ultramafic core had already emerged at the sea floor very shortly after crustal construction. another indication of extreme extension there.

The late phase of igneous activity took place. as we have shown. after the uplift and cooling of the ultramafic core of the Western Limassol Forest, and after the movement on the serpentinite shear zones there too. But, we argue above, the time interval between original crustal construction and the late igneous activity cannot be long because there is no hiatus in lava extrusion in the ophiolite. In addition, the products of this late phase of igneous activity are almost undeformed. The late dyke swarms trend predominantly NE-SW, and we argue in the next section that this is the expected direction for the inside corner model. These relationships are consistent with the occurrence of the late phase of igneous activity as the inside corner terrain passed the spreading centre north of the transform and became welded to the outside corner crust.

Finally, the spatial scales of the features in the Troodos Ophiolite are very similar to those in the ocean. North of the Arakapas Fault, the trends of dykes and faults in the sheeted dyke complex swing around in a dextral sense over about $5 \mathrm{~km}$ from the fault, a similar scale to that seen in the oceans (Fig. 1). The Arakapas Fault Zone itself has a very similar dimension to a single. simple transform fault, made up of a $1 \mathrm{~km}$ wide bundle of fault strands. Within the Limassol Forest. the ultramafic core of the Western Limassol Forest and the Akapnou Detachment are both about $10 \mathrm{~km}$ across, about the size of detachments on the sea floor, and they are separated from the Arakapas Fault by about the same distance as are the core complexes close to the Atlantis Transform.

\section{Controversial questions}

Despite the overall concord between the observations and the inside corner model, there are some questions that remain controversial.

MacLeod \& Murton (1993) and Gass et al. (1994) conclude that the Eastern and Western Limassol Forest formed in very different environments. The deformation in the Eastern Limassol Forest was considered to have been prolonged for long after crustal construction was complete. As we said above, our interpretation of the observations is very different. By contrast, the Western Limassol Forest was considered to be a broad part of the transform zone, and to have been deformed early predominantly by strike-slip tectonics. This conclusion was based on the presence of the east-west vertical serpentinite shears within the ultramafic core. Here we stress that the evidence for extreme extension is more convincing. Extension of the Western Limassol Forest proceeded until mantle rocks were exposed at the sea floor. Where they reach the edge of the ultramafic core, the east-west shear zones produce only minor displacement of boundaries within the bordering crustal blocks. We interpret these shears as strike slip relays connecting sections of detachment fault within the detachment zone, and a relatively minor component of the extensional deformation. In consequence, we conclude that both halves of the Limassol Forest were formed in the same extensional environment, but appear different because they are exposed at different structural levels.

More complex considerations arise in relation to the sense of slip on the transform. Our model of the Limassol Forest as an inside corner terrain in which the extended crustal blocks deepen structurally to the west. juxtaposed against an outside corner terrain on the other side of the transform, requires that the spreading centre lay to the west, and that the transform fault had a dextral offset, sinistral slip. By contrast MacLeod \& Murton (1993) and Gass et al. (1994) conclude that the transform had a sinistral offset, dextral slip, drawing their conclusion principally from palaeomagnetic studies of rotations in the sheeted dykes north of the transform.

As the Arakapas Fault is approached from the north, the trend of the sheeted dykes in general rotates progressively clockwise, over about $5 \mathrm{~km}$, from the regional north-south trend until, close to the Arakapas Fault, the dykes run almost east-west (Figs 2 and 3). In the oceans, the trend of the volcanic ridges that characterize most of the ocean floor. whatever the spreading rate. also often swings around over the last few kilometres as a transform fault or fracture zone is approached. This curving of the trend of the ridges is most marked in the outside corner regions (Fig. 1), but even there it is not invariable. Clockwise rotation of the trend of volcanic ridges is associated with dextrally offset. sinistrally slipping transforms, while anticlockwise rotation is associated with 
A

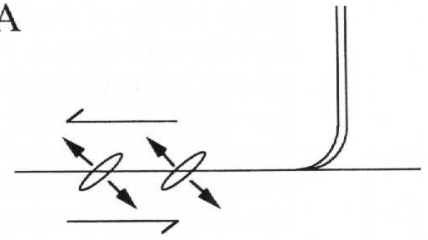

B

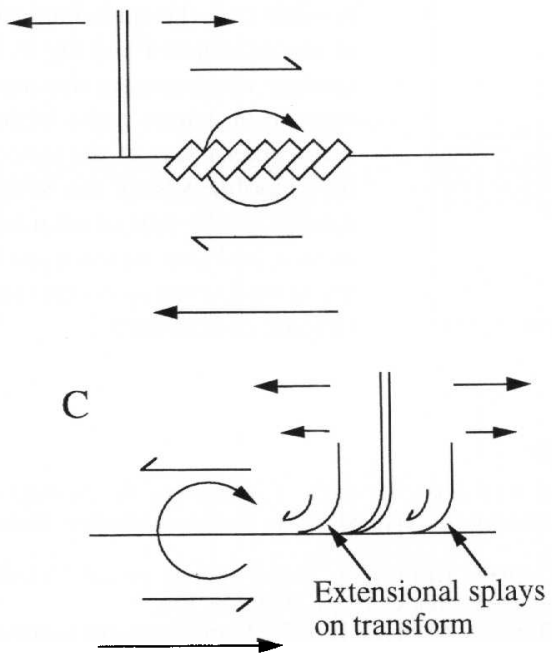

Fig. 7. Three contrasted models to explain the curvature of the dyke trends north of the Arakapas. (a) Searle model: rotation of the stress field close to a dextrally offset, sinistrally slipping transform, with intrusion of dykes into the rotated stress field. (b) MacLeod model: bookshclf rotation of dykes after original intrusion north-south. between two plates in a sinistrally offset, dextrally slipping transform. (c) Ron \& Eyal model: rotation of dykes at the transition from extension to strike-slip, by listric-type sliding, in a dextrally offset, sinistrally slipping transform. The sense of curvature observed near to oceanic transform faults is compatible with model (a) or model (c), which may operate together, but is not compatible with model (b).

sinistrally offset, dextrally slipping transforms. Since the curvature of the volcanic ridges likely reflects curvature in the trends of the dykes feeding the ridges, this evidence taken empirically would suggest that the Arakapas Fault formed at a dextrally offset, sinistrally slipping transform, in agreement with the conclusion from the direction of structural deepening of the extensional blocks (see Fig. 6a).

The rotation of the trend of the volcanic ridges in the oceans, and hence the clockwise rotation of the dyke trend in Cyprus, has been ascribed to rotation of the stress field as the strike-slip faulting of the transform is approached (Searle 1983: Varga \& Moores, 1985; Murton \& Gass 1986). In this model (Fig. 7a), dykes are intruded into fractures that open obliquely to the plate extension direction but perpendicular to the extension direction in a strike-slip shear zone (Searle 1983). Since this model predicts the correct sense of rotation, it has been widely accepted in the oceans. In Cyprus, it has been shown to be inadequate. Palaeomagnetic measurements have been made of dykes from the sheeted dyke complex north of the Arakapas Fault (Bonhommet et al. 1988; Allerton 1989; MacLeod et al. 1990), and these show that the magnetic vector of the dykes rotates as the trend of the dykes rotates. This demonstrates that the dykes were not intruded into oblique fissures, but have been rotated clockwise after intrusion.

The palaeomagnetic results have been used in Cyprus to argue that the dykes have been rotated clockwise by bookshelftype faulting associated with dextral strike slip faulting (MacLeod \& Murton 1993), and thus that the transform was dextrally slipping, sinistrally offset (Fig. 7b). That would mean that a rotation that in the oceans is associated with one sense of slip on the transform would in Cyprus be associated with the opposite sense of slip, despite the close similarity in spatial scale of the rotated units and the magnitude of rotation in both cases. Is it possible to find a mechanism which allows the evidence from the oceans to be reconciled with that from Cyprus?

On one count, both current models are clearly incorrect. Both depend on dyke intrusion into a well-developed strikeslip environment, and yet dyke intrusion in fact happens at the tip of the strike slip fault, at a point in time and space where strain changes from strike-slip to extension, where extension is taken up both by dyke intrusion and by normal faulting. Though the inside corner crust may be modified by strike-slip tectonics as it moves along the active transform. the same cannot be said for the outside corner crust, which is rapidly moved out of the deforming zone at the ridge-transform intersection into the passive fracture zone. And yet it is in outside corner crust that the curvature of the dyke trend is most marked.

It is possible that the rotation of the dykes is associated with strike-slip splays curving from the tip of the active transform (Fig. 7c). In bookshelf terms, this corresponds, instead of shear of books between two plates, to the pulling away of books at one end of a shelf, with the subsequent rotational slipping of the remaining books. The geometry corresponds closely to that of a listric normal fault (e.g. Wernicke \& Burchfiel 1982) if it is rotated until the listric sole is vertical. In this orientation, the sole of the listric fault would correspond to the transform, and the curving listric fault strands to the extensional splays at the end of the transform. An example of this geometry in a strike-slip environment occurs at the north end of the sinistrally slipping Dead Sea Transform, where regions on the west (extensional) side of the fault have been rotated clockwise by slip along splays from the fault which are in part strike slip and in part extensional (Ron \& Eyal 1985). This demonstrates that clockwise rotation near the extensional tip of a strike-slip fault may be connected with a sinistrally slipping strike slip fault. and allows the reconciliation of the evidence from the oceans with that from Cyprus (Fig. 8).

For these reasons, we prefer to use the empirical evidence from the outside corner crust in the oceans, and conclude that the rotation of the trend of the dykes north of the Arakapas is consistent with the sense of structural deepening in the extensional blocks in allowing the inside corner model to stand.

\section{Conclusions}

We conclude that the model of the Limassol Forest as an inside corner terrain has much to recommend it. It explains the geological history of the Limassol Forest, the sequence and timing of the igneous and deformational events there, in a simple way, and explains too its relationship with the Troodos ophiolite north of the Arakapas Transform Fault. The points 


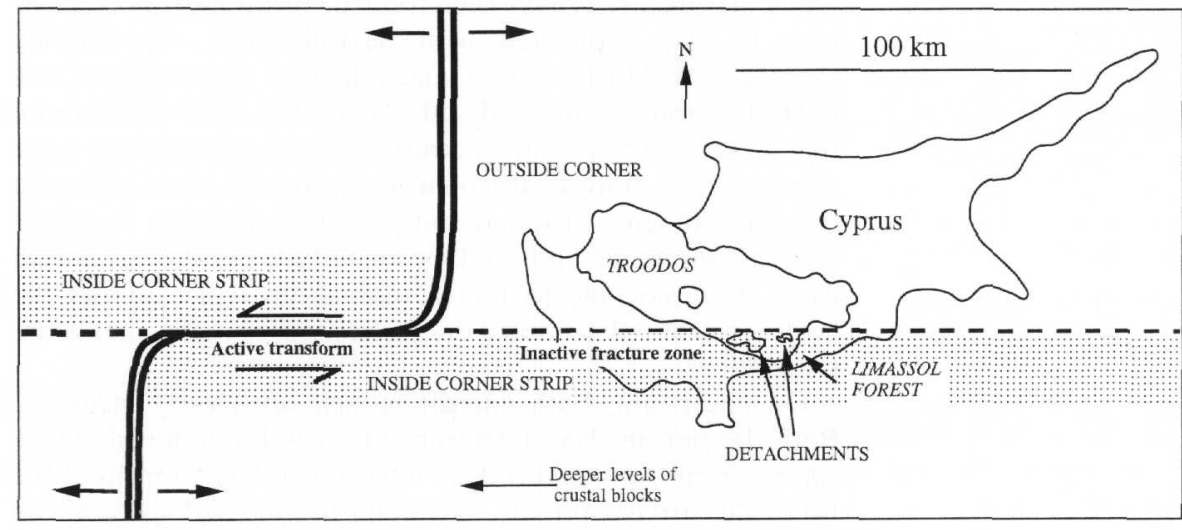

Fig. 8. Outline of Cyprus and the Troodos ophiolite superimposed on the tectonic model proposed in this paper. In this model, the ophiolite is considered to have formed to the east (in its present orientation) of a dextrally offset. sinistrally slipping transform fault, and the Limassol Forest is considered to have formed as part of an inside corner strip south of the transform. It is possible that the spreading centre north of the Arakapas Fault lay in the Solea Graben which crosses the circular outcrop of mantle rocks in the centre of the northern part of the ophiolite. but the ophiolite west of the Solea Graben would then be part of an inside comer terrain. and that region does not show the extreme extension expected of such a tectonic environment. that might be considered to weigh against this interpretation are capable of other explanations. The main weaknesses of the model arise from our relative ignorance yet of the tectonic processes that shape oceanic transform regions. Further investigations of oceanic transform faults will certainly help to test this model, and it may be possible to reach a situation where additional geological investigation of the Limassol Forest may in turn shed light on the processes occurring in inside corner regions.

If this model does survive those tests, it has important implications for the tectonic environment in which the Troodos ophiolite formed. MacLeod \& Murton (1993); and Gass et al. (1994) place the ophiolite as straddling an dextrally slipping transform, which became inactive before the crust moved out of the transform domain. In that interpretation, the spreading centre north of the transform would lie to the west, and that south of the transform to the east, so that both north and south of the transform would be segments of inside corner crust, and would be parts of two different plates, the Troodos and Anti-Troodos plates. In that model, the spreading centre would have lain east of the Limassol Forest, the opposite of our prediction.

Our model is summarized in Figure 8 . In this, the Troodos ophiolite would have formed on the eastern side of a sinistrally slipping transform, and both the Limassol Forest and the Troodos ophiolite north of the Arakapas Fault would have been parts of the same plate, sections of inside corner and outside corner terrains respectively. The key pieces of evidence for this model come from the identification of the Limassol Forest as an inside corner terrain, and the polarity of extension in the Limassol Forest. Curvature of the dyke trends is in the direction expected from this geometry, based on oceanic examples, and the occurrence and orientation of the late NE-SW dyke swarm in the Limassol Forest is also consistent with the model.

This research draws directly on the results of NERC-supported Charles Darwin Cruise 100. We acknowledge gratefully many discussions that helped to clarify the issues involved. and especially with Sara Spencer, Rob Butler, Helena Griffiths, Lisa Tauxe, Jim Hawkins. Steve Freeman, Richard Collier. Chris MacLeod. Jefl Gee and Andy Barnicoat. We benefited from a pereeptive review from Brian Tucholke.

\section{References}

AGAR. S.M. \& KIITGORD. K. 1995. A mechanism for decoupling within the oceanic lithosphere revealed in the Troodos ophiolite. Narmic. 374. 232238.

Allzeros. S. 1989. Distortions. rotations and crustal thinning at ridgetransform intersections. Nature, 340, 626628

BALl.ARD, R.D. \& VAN AXDEL. T.H. 1977. Morphology and tectonics of the inner rift valley at lat. $36^{\circ} 50^{\prime} \mathrm{X}$ on the Mid-Atlantic Ridge. Golegicat Societs of Anerice Bullein, $88,507530$.

BraR. L.M. \& MORFL. S.W. 1960. The geology and nineral resoluads of the Agros Akrari wea. Geological Survey Department. Cyprus. Memoirs. 7 Government Printing Office. Cyprus.

Bi.Ackmav, D.K. CaNN, J.R.. Jansses, B. \& SMith. D.K. 1998. Origin of extensional core complexes: evidence from the Mid-Atlantic Ridge at the Atlantis Fracture Zone. Jound of Geophlysical Reseurch. 103. 21315 21333 .

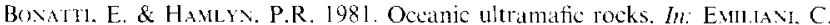
(ed.) The Occanic Lithosphere. The Sea. 7. Wiley-Interscience. New York. $241-283$

Bovatti. E. \& Michaer, P.J. 1989. Mantle peridotites from continental rifts to ocean basins to subduction zones. Earth and Planetary Scione Lothers. 91. $297-311$.

Boniomiat, N.. Roprerch. P. \& Cal.za. F. 1988. Palacomagnetic argument for block rotations along the Arakapas Fault (Cyprus). Goologr. 16. $422-425$

Buck. W.R. 1988. Flexulal rotation of normal faults. Tétonics. 7, 959 973.

Cani, J.R., Biackman, D.K. Smith. D.K.. MCAllistlk. E.. Janssen, B. Mrloo, S. Avgtrisos. E.. PAscot. A.R. \& Escartin. J. 1997. Corrugated slip surfaces formed at ridge transform intersections on the Mici-Allantic Ridge. Nature. 385. 329-332.

Canint. M.. Mevil, C.. Mala, M.. Depeles, C.. Derand, C.. Glite. P.. Agrinier. P. Brlarouchi. A. Duhussox. G. Hl mier. E \& Reyolus, J. 1995. Thin crust. ultramafic exposures, and rugged faulting patterns at the Vid-A lantic Ridge ( $22^{\circ} 24^{\circ} \mathrm{N}$ ). Goologr, 23. 49-52.

Collette, B.J. 1986. Fracture zones in the Vorth Atlantic: morphology and model. Iotwat of the Geological Suciets. London. 143, 763-774.

Cowit. P.A.. Schor.7. C.H.. Edwariss. M. \& Malinver:o. A. 1993. Fault strain and seismic coupling on mid-ocean ridges. Jommal of Gerophysiral Reseurch. 98. $17911-17920$.

DAvis, G.A. \& LISTtR, G.S. 1988. Detachment faulting in continental extension: perspectives from the southwestern L.S. cordillera. In: Clakh. S.P. Blikchfite, B.C. \& Strpe, J. (eds) Processes in Contininal Lithowheric Defomation. Geological Society of America Special Papers. 218 $133-159$

1)1: Chabafir:R. J.-B. \& Avolac. J.-P. 1994. Kinemalics of the Asal Rif (Djibouti) determined from the deformation of the Fieale voleano. Science. 265. $1677-1681$.

Dick. H.J.B. BRyaN, W.B. \& Thompsox, G. 1981. Low angle faulting and steady state emplacement of plutonic rocks at ridge-transform intersections. EOS. 62, 406

DiCK. H.J.B. 1989. Abyssal peridolites. very slow spreading ridges and ocean ridge magmatism. In: Saunders. A.D. \& Norry, M.J. (eds) Magmatism in the Ocean Basins. Geological Society. London. Special Publications. 42. $71-105$. 
Dictrich. D. \& Sirverer. S. 1993. Spreading-induced faulting and fracturing of oceanic crust: examples from the sheeted dyke complex of the Troodos ophiolite. Cyprus. In: Prichard, H, M., Al abastler, T.. Harris, N.B.W. \& NEARY. C.R. (cds) Magnatic processes and plate tectomion. Geological Society. London. Special Publications. 76. 121-139.

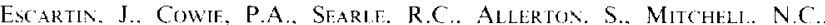
MaCLEod. C.J. \& Slootweg. A.P. 1999. Quantifying tectonic strain and magnatic accretion at a slow-spreading ridge scgmemt. Mid-Atlantic Ridge. $29^{\circ} \mathrm{N}$. Journal of Geophysical Rescarch. 104. 10421-10437.

GxLlO D.G Fox. P.J \& MACDONalD, K.C. 1986. A Sea Beam investigation of the Clipperton Transform Fault: the morphotectonic expression of a fast-slipping plate boundary. Joumal of Geophrsical Rescuen. 91. 3455 3467

Gass. I.G. 1960. The geology and mineral resomes of the Dhati ated Geological Survey Department. Cyprus. Memoirs. 4. Government Printing Office. Cyprus

Gass. I.G. 1968. Is the Troodos massif of Cyprus a fragment of Mesozoic ocean floor? Nature. 221. 926.930

Gass. I.G. MacLeod, C.J., Murton. B.J.. Pavayiotol, A. Simonian, K.O. \& Xexophostos, C. 1991. Geological map of the Simth Troodes Transform Fath Zone at 1:25,000: She'ts I inew ent? ' east). Geological Survey Department. Nicosia, Cyprus.

Gass, I.G. Mac Lfom, C.J. Murton, B.J.. Panayiol tol, A. Simonian. K.O. \& XeNopHostos, C. 1994. The geology of the Southern Troodos Tranctom Zone. Geological Survey Department. Cyprus. Memoirs, 9

JoHx, B.E. 1987. Geometry and evolution of a mid-crustal extensional fault system: Chemehuevi mountains. southeastem California. In: Coward. M.P., Dewty. J.F. \& Haxcock. P.L. (eds) Contintent Extensionat Tectonics. Geological Society of London Special Publications, 28, 312339.

Karson. J.A.. Thompson, G., Hliphris. S.E., Edomond, J.M.. Bryan. W.B. Browx. J.R. Winters. A.T., PoCkalNy. R.A.. Casey, J.R.. Campbell. A.C. Klinkhammer. G. Palmer. M.R. Kinzler. R. \& Stlanowska. M.M. 1987. Along-dxis variations in seafloor spreading in the MARK area. Vature. 328, 681 685

KARSON, J.A. \& DiC K. H.J.B. 1983. Tectonics of ridge transform intersections at the Kane l-racture Zone. Marine Geophrsical Reseafches. 6. 51-98.

KiRSON, J.A. \& LAWRE.VCE. R.M. et al. 1997 a. Tectonic window into gabbroic rocks of the middle oceanic crust in the MARK area near sites 921-924. Procedings of the ODP Scientific Results. 153, 61-76.

KARSON JA \& LAWREVCE. R.M et al 1997h. Tectonic setting of serpentinite exposures on the western median valley wall of the MARK area in the vicinity of site 920. Procededings of the OOP Scicntific. Results. 153 $5-21$.

KarSOx JA 1999. Geological investigations of a lineated massif at the Kane transform: implications for oceanic core complexes. Phitosophical Tiansacions of the Royd Soctery of London. A357. 713-740.

Macbotiat.D. K.C. 1982. Mid-ocean ridges: fine-scale volcanic, tectonic and hydrothermal processes within the plate boundary zone. Ammal Revions of Earth and Plantury Science. 10. 155-190.

Macdonald, K.C.. Castillo. P.A., Mil.t.r. S.P.. Fox, P.J., Kastens, K.A. \& Bonatti. E. 1986. Deep-tow studies of the Vema Fracture Zonel: tectonics of a major slow-slipping transform fault and its intersection with the Mid-Atlantic Ridge. Joumal of Geophisited Research 91. 3334 3354

MACLEOD, CJ. 1990. Role of the Southern Troodos Tansform Fault in the rotation of the Cyprus microplate: evidence from the eastern Limassol Forest complex, In Malpas, I Moorfs, E. Pavayiotol, A. \&

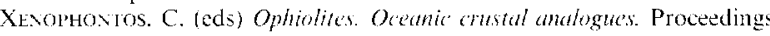
of the "Troodos 87" Symposium 7586 Geological Survey Department Nicosia Cyprus.

MacLeod, C.J.\& Murtox, B.J. 1993. Structure and tectonic evolution of the Southern Troodos Transform Fault Zone, Cyprus. In: Prichard, H.M. Alabaster. T.. Harris, N.B.W. \& Veary, C.R. (eds). Magmatic processes and plate tectenics. Geological Society. London. Special Publications, 76. $141 \cdot 176$.

Macleot, C.J.. Aliferton. S.. Gnss. I.G. \& Xenophontos. C. 1990. Structure of a fossil ridge-transform intersection in the Troodos ophiolite. Nafluc 348. $717-720$

Madsex. J.A.. Fox. P.J. \& MaCdoNaLd, K.C. 1986. Morphotectonic fabric of the Orozco transform fault: results from a Sea Beam investigation. Joumal of Geophlstical Resedirch, 91, 3439-3454.

MCAllisTer E 1995. Tectonic processes on the Mid-Athanic Ridge. PhD Thesis. University of Leeds
Mal pas. J., Calon. T. \& Souiris. G. 1993. The development of a Late Cretaceous microplate suture zone in SW Cyprus. In: Pricharu. H.M. Ai.alaster, T., Harris, N.B.W. \& Neary. C.R. (eds) Magmatic procesces and plute toctonies. Geological Society. London. Special Publications. 76. 177195.

Mivfi. C. Cannat. M. Gevte, P. Marion E. Alzinioe, J.M. \& Karson J.A. 1991. Emplacement of deep crustal and mantle rocks on the west median valley wall of the MARK area (MAR, $23^{\circ} \mathrm{N}$ ). Tecromophysics, 190 3153.

Mitchell. N.C., Escartis, J. \& Ailigrton. S. 1998. Detachment faults at mid-ocean ridges. EOS. 79.127

Monres. E.M. \& VINE. 1.J. 1971. The Troodos massif. Cyprus, and other ophiolites as oceanic crust: evaluation and implications. Philosophical Transactions of the Rotal Socicty of London. A268. 443-466.

MLkius. B.J. \& Gass. I.G. 1986. Western Limassol Foresl complex. Cyprus part of an Cpper Cretaccous leaky transform fault. Geology. 14, 255258

MLrTON, B.J 1989. Tectonic controls on boninite genesis. $I n$. SAL Vibers A D \& Norry. M.J. (eds) Magnatism in the Ocean Basins. Geological Society. London, Special Publications, 42. 347-377

Murtox. B.J. 1990. Was the Soulhern Troodos Transform Fault the victim of microplate rolation? In: MalPas, J., MoORls, E. PANayiotol A \& Xr:Nophontos. C. (eds\} Ophiolites. Oceanic crustal analogues. Procecting of the "Troodos 87 " Sympersm. Geological Survey Department. Nicosia. Cyprus. 87.-98.

OTTER TlAM 1985. The geology of the Oceanographer transform: the transform domain. Marine Geoplysal Researches. 7.329358.

PANIALIS. T.M. 1967. The geolog. and minerat resources of the Phamakas Kutarases area. Geological Survey Department. Cyprus. Memoirs. 8. Government Printing Office. Cyprus.

PARson. L.M. \& SEarif. R.C. 1986. Strikc-slip fault styles in slow-slipping oceanic transform faults: evidence from GLORIA surveys of Atlantis and Romanche fracture zones. Jotrinal of the Geological Societr. Lombon. 143 $757-761$.

Rov. H. \& Fyal. Y. 1985. Intraplate deformation by block rotation and mesostruetures along the Dead Sea Transform. Northern Isracl. Tectonics. 4. $85-105$

SEARle. R.C.\& Laughrox. A.S 1977 Sonar studies of the Mid-Atlantic Ridge and Kurchanov Fracture Zone. Jownal of Gophisical Resewd 82. $5313-5328$

Stari.f. R.C. 1983. Multiple, closely-spaced transform laults in fast-slipping fracture zones. Geologr. 11.607-610.

StARLE, R.C. 1986. GLORIA investigations of oceanic fracture zones: comparalive study of the transform fault zone. Jommal of the Geoleggical Societs. London, 143, 743-756.

Severinghats. J.P. \& Macbovalo, K.C. 1988. High inside comers at ridge transform intersections. Marine Gophlsical Researches. 9. 353367

Simoniav, K.O. \& Gass. I.G. 1978. Arakapas fault belt Cyprus: a fossi transform fault. Geologicai Socted of Anerica Bulletm. 89. 1220-1230.

Smith, D.K. \& CAN J.R. 1993. Building the crust at the Mid-Allantic Ridse. Nature. 365. 707715.

SMITH, D.K. \& CANN. J.R. 1999. Constructing the upper crust of the MidAtlantic Ridge: a reinterprctation based on the Puna Ridgekilauea Volcano. Jotrnal of Geophisical Rescurch 104. 25370-25399.

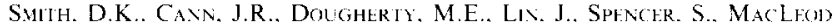
C.. Kheton, J.. McAl. isthr, E.. Brooks. B.. Pascol. R. \& Robirtson. W. 1995. Mid-Atlantic Ridge voleanism from deep-towed side-sean sonar images $2529^{\circ} \mathrm{N}$. Joumal of Folowoligy and Gonthemal Rescarch. 67. 233262.

SMiTh, D.K.. TiveY. M.A. SchouteN. H. \& CAN. J.R. 1999. Locating the spreading axis along $80 \mathrm{~km}$ of the Mid-Alantic Ridge south of the Atlantis Transform. Joumd of Gorphisical Resewh 104. 75997612

TLCIInkE, B.E. \& Liv, I. 1994. A geological model for the structure of ridge segments in slow spreading ocean crust. Joumal of Gophisital Rescarch. 99. $11937-11958$

TLCHOLKF. B.E.. LIN. J. \& KI.FINROCK, M.C. 1998. Megamullions and mullion structure defining oceanic metamorphic core complexes on the MidAtlantic Ridge. Joumal of Geophisical Research. 103. 9857-9866.

VARGA, R.J. \& Moores. E.M. 1985. Spreading structure of the Troodos ophiolite. Cyprus. Gology 13.846850.

Wernicke. B. \& BLrchfil: L. B.C. 1982. Modes of extensional tectonies. Jommal of Siructuril Geologr. 4. 105115

Zervas, C.E.. SEmp'ERe. J.-C. \& LiN, J. 1995. Morphology and crustal structure of a small transform fault along the Mid-Atlantic Ridge: the Atlantis Fracture Zone. Marine Geophsical Researches. 17. 275300. 